\title{
Construction History in Theory and Teaching
}

\author{
Martin Pilsitz ${ }^{1 *}$ \\ ${ }^{1}$ Department for History of Architecture and of Monuments, Faculty of Architecture, Budapest University of Technology and \\ Economics, Building K, II. 82, Müegyetem Rkp. 3, 1111 Budapest, Hungary \\ * Corresponding author, e-mail: pilsitz.martin@gmail.com
}

Received: 16 September 2018, Accepted: 20 September 2018, Published online: 24 September 2018

\begin{abstract}
For the development of a comprehensive explanative model on the genesis and use of the history of a historic building, an exclusively visual and aesthetic approach is not sufficient. In addition to the function, the construction is also shown as a peer design factor in the planning, architectural and artistic development. In this context, the task of the technical universities and colleges is to provide students with a far-reaching expertise in historical building construction. To achieve this goal, the Budapest University of Technology and Economics (BUTE), in the context of a research programme, has taken a targeted initiative. For this purpose, a large number of historical architectural drawings were combined in a plan collection at the Department and made available for further research. With regard to the structural importance of these drawings, a systematic scientific research has been carried out. This study was supported by the National Research, Development and Innovation Office - grant No. 112906.
\end{abstract}

\section{Keywords}

Civil engineering history, Budapest University of Technology and Economics, historic building materials, Frigyes Schulek, Plan archive

\section{Structural design recognized as a historical value}

The German art historian Johann Joachim Winckelmann (1717-68) is not only the founder of scientific archaeology and art history in Europe, as a mental initiator of classicism in the German-speaking area, he also introduced a strict periodization of architectural history, which, up to now, has had a sustainably lasting effect on representation and teaching of classical history at universities and colleges. ${ }^{1}$ In Winckelmann's explanatory model, architectural forms of expression are divided chronologically and linearly, allowing a manageable system of order. At the same time, based on a visual approach, a rigid structure is created, which focuses on the history of the building, on the basis of an aesthetic understanding. This is not necessarily wrong; however, the building is not explained in a fully understandable way. The architect Rudolf Schwarz (1897-1961) recognised the need for reform in relation to this rigid periodisation. He articulated this in the 1950s, namely, that the history of a building can only be fully explained if the function and design are also recognised as peer design affecting factors (Schwarz, 1953). The construction is indissoluble part of the design and use of a

1 As a research subject today, the history of towns and settlements are also included in the history of architecture. building. This implies that a historical building, alongside the cultural, also has a technical value (Rheidt and Lorenz, 2018). This detail was important for architects and civil engineers already involved at the beginning of the $20^{\text {th }}$ century in their historical and structural considerations. ${ }^{2}$ In recent years, in many countries, societies were founded to explore civil engineering history systematically and on a scientific basis. In Germany, for example, the Gesellschaft für Bautechnikgeschichte (Society of Civil Engineering History) pursues the following aims: "The overall aim is to deal with the technical aspects of the history of the buildings - in research and teaching" (Bautechnik, 2018). In the following, various aspects of civil engineering history will be discussed. Subsequently, the project aiming to explore the plan collection (supported by the National Research, Development and Innovation Office) as an example of the Budapest University of Technology and Economics will be presented. In the framework of this article, not all innovative influencing factors, such as the technical knowledge transfer or the historical development of

2 In 1926, the Georg Agricola-Gesellschaft e.V. (GAG) for the history of technology and industrial culture e.V. (GAG) was founded in Germany, which still exists today (www.Georg Agricola-gesellschaft.de) 
the site organisation, can be comprehensively and conclusively discussed. Rather, the author intended to provide an overview of construction history, with a focus on the 19th Century. The interaction between function, construction and spatial shapes in architecture will be discussed in a subsequent publication.

Regarding construction technology, the $19^{\text {th }}$ Century meant a profound change; the trigger was the industrial revolution (Osterhammel, 2009). Architects and civil engineers were confronted with new construction tasks. The solutions for planning tasks could not be based on historical models. There were new infrastructure buildings, such as railway stations and factories with wide-ranging ceilings or trade buildings, such as multi-storey department stores and storage houses, large exhibition buildings and transparent greenhouses. For the completion of these kinds of construction projects, appropriate technical, organisational and architectural concepts were implemented. This innovative thinking can be demonstrated by the example of the Bauakademie in Berlin (Schinkel, 18321836). Schinkel deals with this building, among others, with questions of technology and the design of the serial production of components. At the same time, he addresses the relationship of form and construction material. In his work, Miron Mislin summarises the essential characteristics of the Bauakademie as follows (Mislin, 2002):

- The constructive and functional structure can be seen on the façade.

- The construction with bricks dominates the structural design and aesthetics.

- The architectural idea corresponds to the functional, constructive and spatial solution of the task.

Schinkel's reflections on style and the selection of building materials is trendsetting for the architecture of the $19^{\text {th }}$ century. With this "technical aesthetic", starts a stylistic direction that will be typical for the construction of barracks, railway stations and hospitals. To ensure an orderly development, the following requirements must be met:

1. Building materials with appropriate properties and in sufficient quantities are available (Stark and Wicht, 1998).

2. A theoretical analysis of architecture, which is no longer based on experience, but on systems (Neumeyer, 2002).

3. Development of scientific calculation methods in structural engineering (Statics) (Mislin, 2002).

\section{Introduction of new building materials}

With the introduction of new building materials, innovative construction methods were developed. Especially with the breakthrough of Portland Cement (1824), the steel profile (1849) and in the glass (1866); all were formative for the construction industry. These materials opened up design possibilities not previously known, but at the same time, also increased the demands on the structural understanding of the planner and construction workers. In general, until about the middle of the 19th century, traditional building construction (i.e. technical solutions in conjunction with local experience and a small number of different materials) had been used. However, from about 1850 , this changes to a universal construction approach (building materials as a mass product, standardisation and prefabrication of components and construction methods that are no longer linked to a specific location) (Pilsitz, 2012).

From the multitude of scriptures and quotes that take a position on this issue, the following examples will be singled out. In his work, it is above all Otto Wagner (18411918) in Vienna, the pioneer of constructive aesthetics and a new architecturally technically determined way of thinking in Europe (Moravánszky, 1988). He formulated his principles, as follows: "Every new style gradually results from the previous, that new designs, new materials, new human tasks and views required a change or reconstitution of the existing forms. ... It is to assume well proven that art and artists always represent their own epoch. ... The purpose of art, even so, the modern, has remained but the same, which was at all times. The art of our time must be modern ... All modern created must comply with the new material that corresponds with the requirements of the subject ... on behalf of the colossal technical and scientific achievements and the practical benefit ..... This new style, the Modern, ... must in all our work clearly express the emergence of fulfillment of purpose. ...." (Wagner, 1896). In this fundamental re-evaluation is Wagner, influenced by Gottfried Semper, who has shaped the following programmatic sentence: "Artis sola domina necc sitas" - "the only ruler of art is the necessity." In his book Wissenschaft, Industrie und Kunst (Science, Industry and Art) Semper rejects to squeeze material in forms that do not comply with its internal law. It can be seen that Semper's attitude is a reflection on French Architecture theories of the $18^{\text {th }}$ Century (Kaufmann, 1952). As a notable addition, Henry van de Velde (1863-1957) should be mentioned. For him, the principles of Wagner were so essential that he enunciated his attitude in 1912, even in the form of "beliefs": 
"You should use this form and construction of all items only in the sense of their strict logic and raison d'etre. You should adapt and subordinate these forms and constructions to the essential use of the material you use." (Huning, 2007).

In summary, it should be noted that Otto Wagner and van de Velde repeatedly emphasise in their writings the direct link between the proper application of the building material (and thus as a result of the construction) and the architectural form (Velde, 2003). The following provides an overview of the new construction material introduced during the period under investigation (Wagenbreth, 1995):

\section{8/1779 Earliest cast iron bridge in England}

The construction of the Coalbrookdale Bridge (span 30 meters) provided evidence that structures could be created entirely from iron. The parts of the bridge were cast in 1778 at the local foundry in Coalbrookdale. They were then assembled at the construction site in 1779. The successful use of iron in bridge construction was the starting point for the new material's application in building construction. The roof of the Théâtre Français (1786, Victor Louis) and the dome over the Corn Exchange in Paris (1811, Belanger \& Brunet) were built using iron after the original wooden structures had been destroyed by fire. (Ackermann, 1994)

\section{Cast iron column}

Based on practical experience, it was realised that cast iron had a low tensile strength. Therefore, mainly components subjected to compression have been produced: supports and columns.

1783 Rolled steel in England (in Germany around 1840) With this method, it was possible to roll out steel plates and sheets from a solid block of steel. Later, steel bars for concrete reinforcement were manufactured using this method.

1784 Steel (using "puddling")

The Englishman Henry Cort produced, by applying the stirring procedure, iron of high quality that could be used to produce wrought iron construction parts. Steel could then be produced using a hardening agent. Using this material, the roof system "King \& Queen Post Roofs" was developed in England, which anticipated the truss system. Platform halls with large spans could now be realised, such as the construction of Euston Station in London in 1835.
A further architectural development is related to the combination of cast iron curvature beams, which were mounted using wrought iron tie rods. This idea of reinforcement is reflected in the development of reinforced concrete.

\section{Roman cement}

Roman cement became the primary binding material throughout Europe between 1790 and 1850.

\section{4/1844 Portland cement}

In 1824, the Englishman Joseph Aspdin received a patent for Portland cement, the quality of which further improved after 1844 by means of sintering. Using Portland cement, it was possible to make bricks from lime or cement-based material.

\section{Steel profiles: U-beams I-beams}

With the introduction of riveted joints, single profiled steel pieces could be attached to each other in such a way that the resulting iron construction acted as a unit. The prerequisite for this construction method was the introduction of scientifically based analytical and calculation methods.

\section{Rotary Kilns}

Following the introduction of this industrial furnace, cement could be produced in a continuous process.

\section{Bessemer steel}

The Bessemer process mechanised the production of steel: Compressed air (produced by steam engines) was blown into the molten steel, whereby unwanted material was separated from the iron. In addition to the quality, the production volume was increased: In 1850, a worker produced on average about eight tons of pig iron per year, whereas, by 1870 , the amount had increased to 80 tons.

\section{Schlickeysen's auger brick press}

After the invention of moulding presses for clay and brick kilns, the auger brick press became an industrial item. Phases of innovation in the manufacturing techniques for auger brick presses were:

1819: Brick machine by Doolittle

1824: Brick machine by Delamoiriere

1855: Brick press by Schlickeysen

1857/58 Hofmann kiln

The Hofmann kiln was the first kiln to deliver, using a continuous ring of fire, consistent quality of brick. 
Moreover, the Hofmann kiln could be operated without interruption, which further enhanced production figures and reduced material costs.

1858 Crusher for the production of gravel \& split gravel

The crusher enabled the production of large amounts of gravel \& split gravel.

1860 Roofing Felt

1867 Reinforced concrete (Germany 1884)

\section{7/68 Glass tray for glass production}

This method was used to mechanise the production of window glass. Window glass production thus became an industrial procedure.

\section{Thomas steel}

The production of steel according to the Thomas procedure is a further development of the Bessemer process.

1894 Roll forming machine with panels of glass

This process enabled the large-scale production of sheets of flat glass. (Further development: Foucault, 1904)

\section{About 1900 Monolithic concrete, pre-cast concrete}

In the $19^{\text {th }}$ century, mass production became possible for the materials listed above. This meant the large-scale use of iron, steel and glass in construction. The mass production of bricks enabled their use as a replacement for stone. The mass production of cement using rotary kilns and the mass production of sand \& gravel in the late $19^{\text {th }}$ century increased the use of concrete constructions. Roofing felt meant that large buildings (railway station) could have flat roofs (Wagenbreth, 1995).

\section{Innovative components}

In addition to individual materials, prefabricated components were also developed, such as columns and stairs made of cast iron, or ventilation elements made of sheet steel. These elements were manufactured in factories, transported to the building site as prefabricated elements and assembled there. The application of these components required a new way of thinking in the planning and organisation, which became the basis for a future rationalised construction with prefabricated components. The glass palace of Joseph Paxton, which was developed for the World Exhibition in the year 1851, shows the concept of a raster systematisation. The exhibition hall is made up of horizontal and vertical prefabricated modules (cast and wrought iron) in a grid of $7.30 \mathrm{~m}$ (McKean, 1994). Siegfried Giedion describes the Crystal Palace as "the creation of a new way of construction site thinking, for which there is no model" (Giedion, 1928. p.5.).

\section{Developments in structural engineering}

The development of scientific calculation methods for structural engineering was one of the most important prerequisites for the development of civil engineering (Kurrer, 2002). In addition to the proof of stability, the economic use of the building material was particularly important; this was also in the economic interests of investors. During the 19th Century, a variety of calculation procedures were introduced to ensure correct dimensions for structural components (Baustatik, 2018). ${ }^{3}$

3 Johann Albert Eytelwein (1764-1848): Support forces of the continuous beam, Euler-Eytelwein Formula

Louis Poinsot (1777-1859): Power couple in 1803

Claude Henri Navier (1785-1836): The theory of the suspension bridge in 1823; the first comprehensive structural analysis; technical bending doctrine in 1826; investigation of statically indeterminate beam structures.

Jean Victor Poncelet (1788-1867): Pioneer in the field of technical mechanics (1826-1832), and projective geometry (1822); In 1835, earthvaulted theory;

Augustin Louis Cauchy (1789-1857): Theory of elasticity, voltage concept, 1840.

George Green (1793-1841): The foundation of the potential theory for Mathematical PhysicsGabriel Lame (1795-1870): First monograph on elasticity theory, 1852

Barre de Saint-Venant (1797-1886): Principle of St. Venant torsional strength in teaching theory

Emile Clapeyron (1799-1864): Clapeyron theorem, three torque equation at the continuous beam, 1857.

William John Macquorn Rankine (1820-1872): In 1856: Earth Pressure theory; further contributions to individual static questions to buildings in 1858

Karl Culmann (1821-1881): Timber frame theory 1851; graphic statics 1866.

Gustav Robert Kirchhoff (1824-1887): Plate Theory

Federico Luigi Menabrea (1809-1896): Set of Menabrea on energy to change form of statically indeterminate systems (principle of Castigliano and Menabrea)

Jacques Antoine Charles Bresse (1822-1883): Theory of the elastic sheet, core of the cross section

Johann Wilhelm Schwedler (1823-1894): Half-timbered theory in 1851, Schwedler carrier, Schwedler dome, three joint system Enrico Betti (1823-1892): Set of Betti, 1872

Georg Rebhann (1824-1892): Tension analysis for simple symmetrical beam cross-sections in 1856, Earth Pressure theory 1870/1871 


\section{Typical constructions}

In the following, three building constructions are shown that are exemplary for the $19^{\text {th }}$ century:

\subsection{Vaulted brick cap}

This vaulted ceiling consists of aligned segment barrel vaults, where two parallel double-T-carriers made of steel provided the abutment. Sometimes railway carriers were used for this purpose. In between, there are flat segment-shaped barrel vaults made of bricks. This historic structure was often used in the $19^{\text {th }}$ century as a static system for floor slabs in residential buildings and industrial buildings. Compared to a wooden construction, this ceiling is more resilient and resistant against humidity. Typical building damage of this construction is the corrosion of the iron girder.

\subsection{Polonceau truss girder}

The Polonceau truss girder is a special binding type for wide span halls, such as in the case of train stations.

August Ritter (1826-1908): Ritter procedure for statically determined trusses 1861

Luigi Cremona (1830-1903): Graphic determination of the rod forces in static certain specialist networks ("Cremona plan", 1872)

James Clerk Maxwell (1831-1879): Principle of virtual forces for trusses in 1864, reciprocal figures in the half-timbered theory 1864/1867/1870 Emil Winkler (1835-1888): Pioneer in the field of technical theory of elasticity, Winkler's bedding, methods of influence lines (influence lines), theory of the elastic sheet

Christian Otto Mohr (1835-1918): Mohr Coulomb's strength hypothesis; Mohr tension circuit; graphical determination of the Bending Line, principle of virtual forces for trusses

Maurice Lévy (1838-1910): Graphic statics, Earth Pressure theory, plate theory

Hermann Zimmermann (1845-1935): Zimmermann dome

Carlo Alberto Castigliano (1847-1884): Based on this analysis statically indeterminate systems sets of Castigliano

Rudolf Bredt (1842-1900): Bredt's formulas in the strength of materials Jakob Johann von Wyrauch (1845-1917): Formulated the sentence of "influence lines" in 1873, Earth Pressure theory, technical theory of elasticity

Frederick Engesser (1848-1931): Earth Pressure theory, bending theory In addition to calculations were also invented graphical methods: Karl Culmann (1821-1881): graphical method for the statics of trusses. With the graphical statics he has founded a new discipline and thus a number of effective graphical methods of structural analysis. Culmann's motto was: The drawing is the language of the engineer. August Ritter (1826-1908): Developed the so-called Rittersch'en cutting method for the calculation of bar forces in trusses.

Luigi Cremona (1830-1903): Method for the determination of the rod forces in statically determined trusses (Cremona-plan).
Fundamentally, it is a gable roof whose rafters are understretched. The advantage of this construction is that the Polonceau truss girder does not exert side thrust on the walls. The design is simple to calculate because the geometry consists of triangles. At the same time, this support system was quick and easy to make from prefabricated parts.

\subsection{System Hennebique (1892)}

The Hennebique system consists of standardised components such as ribbed ceilings, columns and walls to be poured into a monolithic structure. This is different from the additive systems where ready-to-use supports and beams are placed on top of each other.

\section{Movement as a new phenomenon in architecture}

As a direct consequence of the numerous applications that made possible new building materials and elements as well as construction methods, another phenomenon had a decisive influence on the development of construction and architecture, the movement. Although the Italian-Swiss Futurist Alberto Sartoris is not one of the architectural theorists who influenced the development, his concept of integrating the phenomenon of movement in architecture, is of fundamental importance (SATORIS, 1932). During the $19^{\text {th }}$ century, the physical phenomenon of machine-generated motion fundamentally changed the aesthetic experience of space.

An example is the entrance of a train in a train station hall, in which the perspective of the traveller is constantly changing. ${ }^{4}$ Siegfried Giedion confirms these considerations as follows: "The float glass is part of the essence of the shaft of lifts in ...high-rise buildings are permeated by railways. The fluctuating element is a part of the construction" (Giedion, 1928. p.7.)."

In summary, it should be noted that in the $19^{\text {th }}$ century, a dynamic and irreversible change from a traditional construction to a universal construction was taking place. New materials, in combination with the development of the scientific calculation methods of structural engineering, opened up new construction possibilities s. Additionally, building materials produced using industrial production became mass products. This development was triggered by the need to find solutions for new building projects for which there were no historical models. Architects, such as

4 The movement as a phenomenon of aesthetic perception already thematised in the Gothic period, is taken up again in the $19^{\text {th }}$ century by Viollet-le-Duc and can be traced to the traffic structures of the Spanish architect Calatrava. 
Karl Friedrich Schinkel and Joseph Paxton, explored this concept of technical construction and formulated in this way new creative and constructive principles that allowed a revolutionary perspective on the buildings of the future. This re-evaluation of construction and form lead to new designs (Pilsitz, 2016).

\section{Research project on historic drawings at BUTE}

During the $19^{\text {th }}$ century, the first archives with architectural drawings and illustrations were established in newly created architects' offices and colleges of higher education. One of the reasons for collecting the drawings that were created at the time was to secure the design itself with the drawing. The realised building changes over time, is damaged or is transformed, while the drawing in its original form is maintained. The plan is the medium that contains the original design idea and the structural design, that is, how the building was conceived and made. Whenever something should be converted, extended or repaired, it is an advantage for the future of the building when the planner realises the original building idea. This is even more important the more complicated the buildings have become, i.e. the more sophisticated the constructions have become. Plan archives were not created out of nostalgia but as an instrument of building maintenance by the church building authorities or large companies. However, architectural drawings have not only a practical or cultural-historical value but often a high artistic value of their own in the history of graphic arts, indeed in line with painting; they are by no means only of secondary importance. For example, the invention of perspective is an essential means of modern image display (Nerdinger, 1986). For the universities, there is a didactic interest that is not alone in focussing on drawings, but on all kinds of testimonies of the design and construction process, as well as of the completed building. Thus, in addition to the archives, museums and libraries, the universities are the main public collectors of architectural drawings. As an immediate consequence of the systemisation and professionalisation of the training of architects from the middle of the mid18 th century, collections for teaching purposes were created of plaster casts of components and ornaments, models, engravings and books, prints (later also photographs), and last but not least of course hand drawings of architecture or other origin (Nägelke, 2012).

In the case of Budapest University of Technology and Economics, apart from teaching, the original task of the Department History of Architecture and Monument
Preservation is to concentrate on the collection, archiving and scientific processing of historical architectural drawings. The former department of medieval architecture, for example, inherited a stock of photographs, slides, plaster casts and a variety of disordered architectural drawings. In the framework of the current research project, these drawings were reviewed, sorted, catalogued and digitised. The result of this months-long work is a comprehensive collection of architectural history, which was published as a large-format book in three volumes (In Hungarian: Építeszettörténeti Rajztár Vols 1., 2. and 3.) and thus made available for further research (Krähling et al., 2017). The pictures of the drawings consist of high-resolution photographs, each of which are marked with a catalogue number. This gives a unique identification, which can be referred to for any type of publication. In addition, an infobox is placed next to each figure, which offers a variety of detailed information, such as author, origin, object, scale, character and condition of the drawing (for example drawing) as well as the plan size and drawing technique.

The preparation of the drawings covers the spectrum from pencil sketch to detailed elaboration with different drawing techniques. The illustrations show all methods of architectural visualisation: layout, floor plans, section, views, details, interior and exterior perspectives. As far as the use of colour is concerned, the collection contains mainly monochrome works, although individual polychrome views, perspectives and details can be found. In terms of content, a large number of different construction types and objects are discussed in the period between 1880 and 1966 including: competitions for public buildings, churches, houses, settlement forms, details, ornaments, sections, stairs, windows, doors, profiles of geological formations, as well as descriptions of archaeological excavations. It is assumed that a major part of the work are drawings of historic buildings, which created on-site as part of a building survey. It is remarkable that no factories or other technical constructions, such as rail yards are present. In addition to works that are part of architecture, nude drawings can also be found.

The drawings, which thematise building constructions, naturally show traditional techniques of historical buildings, making the collection a research object for historic building techniques and at the same time usable in teaching. The starting point for consideration is that modern building constructions can only be understood if the fundamental technical problem to be solved is understood. To learn this way of thinking, the understanding of traditional constructions is of 


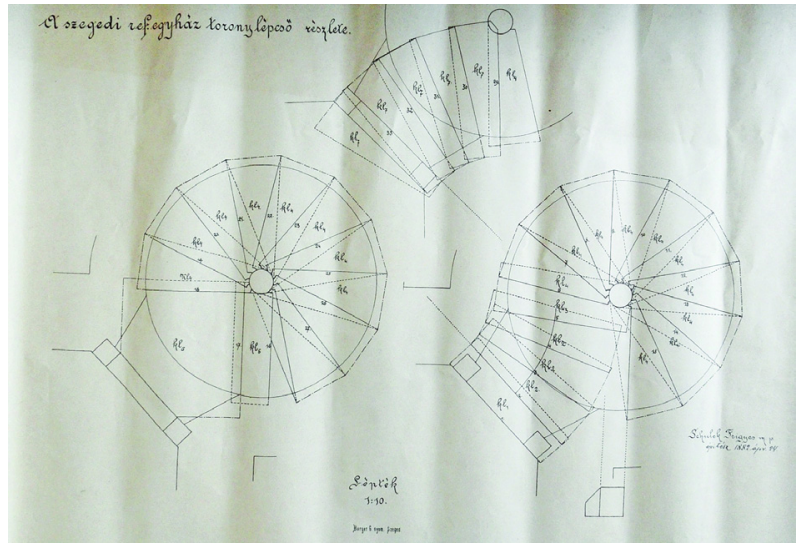

Fig. 1 Church. Staircase plan. Szeged. Frigyes Schulek.1882. Source: Építészettörténeti Rajztár. Volume 1. Drawing no.101726.

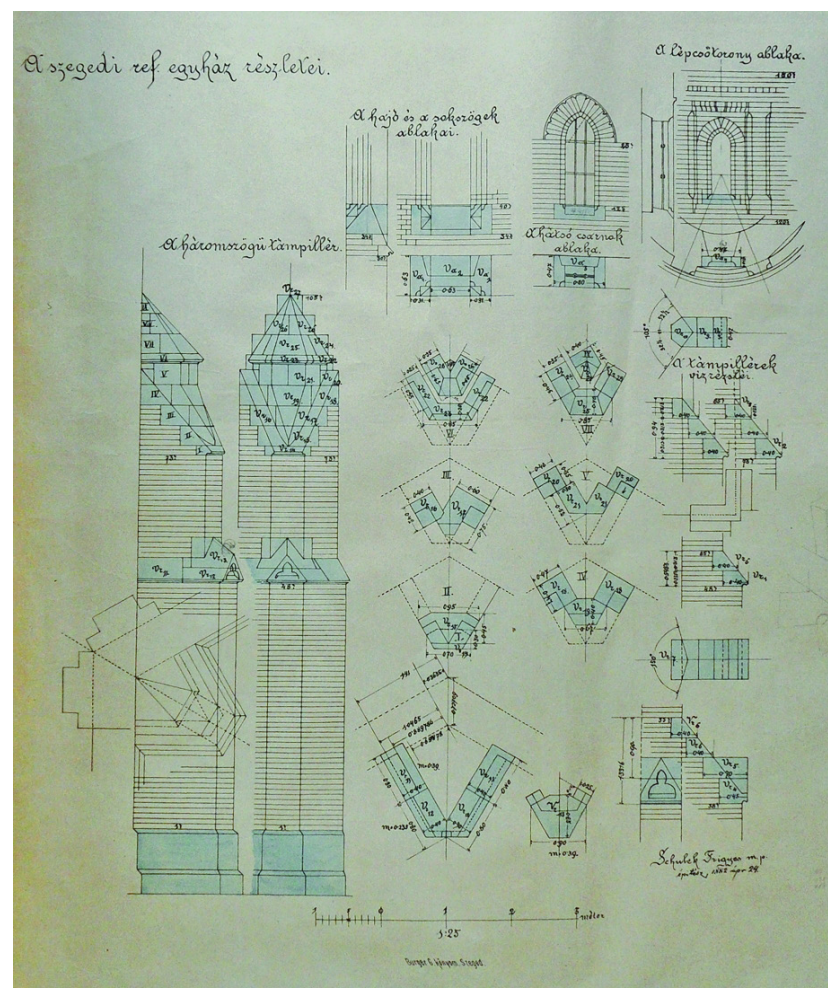

Fig. 2 Church. Details. Szeged. Frigyes Schulek.1882.

Source: Építészettörténeti Rajztár. Volume 1. Drawing no.101736.

great benefit to students of architecture. In this low-tech construction method, the selection of materials is limited and is used optimally, that is economically. In a broader context, a reference to current issues, such as energy and raw material scarcity can be established. The sustainable use of resources has often been an issue in constructing historical buildings, which can be illustrated by model drawings for students. At the same time, no industrial construction techniques are used, but rather a manual construction method. This means, in most cases, an additive and slow construction, the principles of which are easier to understand. In addition, the

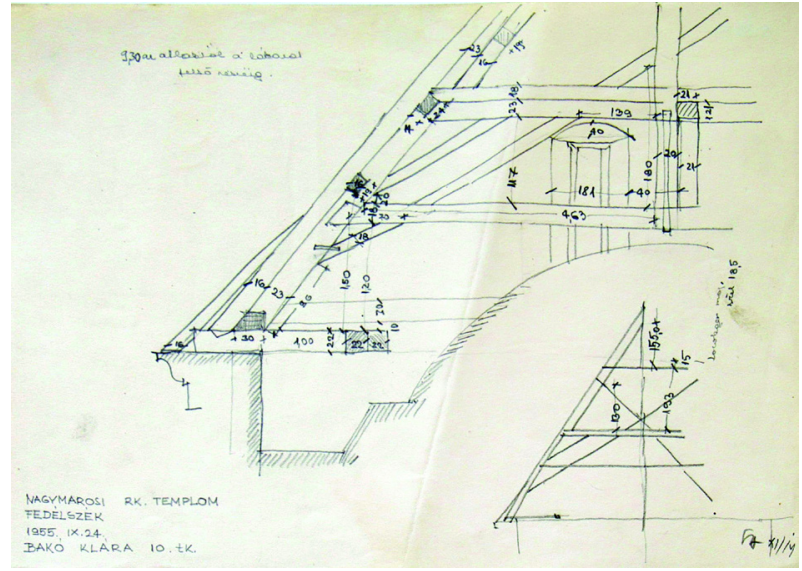

Fig. 3 Roman Catholic Church. Stock roof truss. Nagymaros. Bakó Klára. In 1955.

Source: Építészettörténeti Rajztár. Volume 2. drawing no. 103831

students are taught basic principles, which enable them, in conjunction with practical exercises, to assess historical buildings. These skills are taught by the Department of History of Architecture and Monument Preservation of Budapest University of Technology and Economics, both in regular as well as in postgraduate courses. In addition to diagnostics for the technical condition of a historic building, the right method of documentation should also be learned. The Plan Collection of Historical Constructions could be an integral part of the teaching and research material. ${ }^{5}$

The drawing collection is supplemented by a number of early textbooks on construction available from the predecessor of the Department - the Department of History of Architecture and of Monument Preservation of BUTE. ${ }^{6}$

5 The plan numbers of drawings in the Plan Collection that show technical details are:

Volume 1

100002100010100011100300 100301, 100471, 100538, 100546, 100551, 100588, 100601, 100661, 100664, 100665, 100678, 100742 , 100825, 100831, 100862, 100863, 100951, 100952, 101025, 101308, 101372, 101445, 101486, 101708, 101125, 101726, 101735, 101736, 101834, 101837, 101838, 101839, 101833, 101848, 101852, 101855, 101856, 101917, 101922, 101924,

Volume 2 102001, 102245, 102448102449102451102457 102458, 102870, 102871, 102973, 102974, 103133, 103223, 103266, 103545, 103546, 103558, 103640, 103743, 103764, 103824, 103831, 103944,

Volume 3

104064104234104310104551 104739, 104809, 105093, 105563,

6 The title catalogue of the former department of medieval architecture came to light in the course of the processing of the drawing collection preserved at the Department 


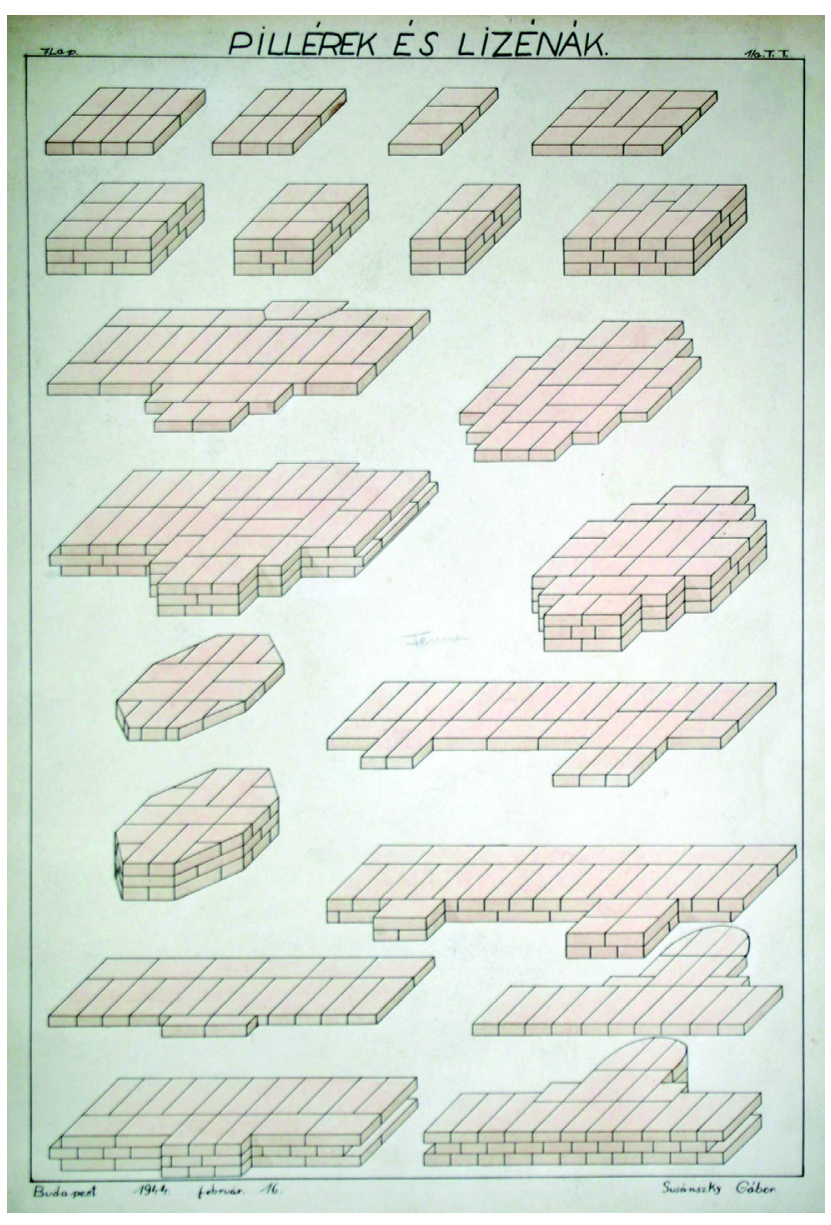

Fig. 4 Columns and Pilasters. Stratification of the brick. Susánszky Gábor. In 1944.

Source: Építészettörténeti Rajztár. Volume 2. Drawing no. 103133.

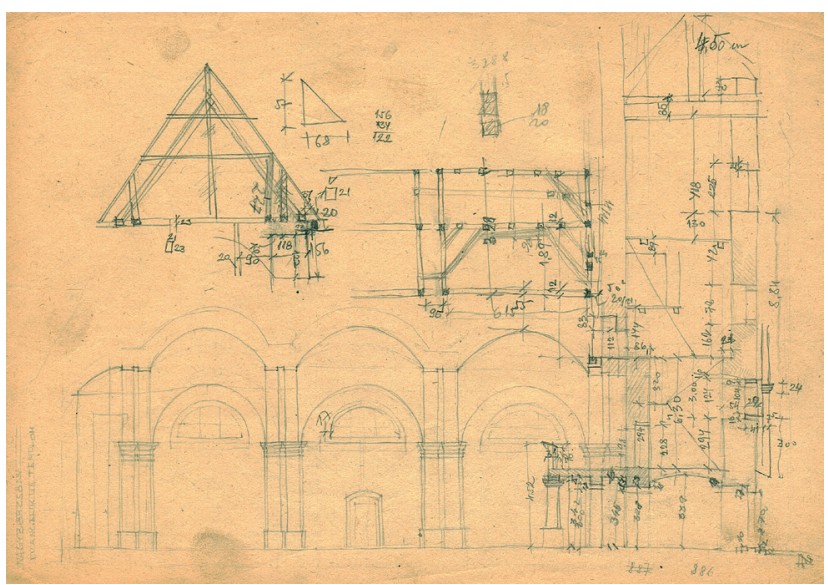

Fig. 5 Evangelical Church. Cut and roof construction. Nagybörzsöny. Source: Építészettörténeti Rajztár. Volume 3. Drawing no. 105563.
The books were used for the theoretical guidance for the designs of meaningful structural solutions and are today important sources of research for civil engineering history. ${ }^{7}$

\section{Summary}

Over the course of the 19th century, construction technology has undergone development from a traditional to a universal practice. The trigger for this fundamental change in the design and construction of buildings was the invention and industrial mass production of new building materials and the development of novel methods for calculating structures. As a result, many innovative buildings have emerged, which today are counted as historic buildings. Some of these buildings dominate entire streets or even carry the identity of individual parts of a city or an entire city. To fully understand these buildings and where appropriate, in order to be able to protect them from decay, knowledge about the former construction methods must not be lost. Rather, these techniques should be systematically explored, documented and taught at universities. In the framework of the research programme, a plan archive of historical architectural drawings was created, which is scientifically investigated by the researchers on methods of construction.

\section{The most important books on constructions are:}

Dr. Heinrich Leibnitz: Die Organisation der Gewölbe im christlichen Kirchenbau. Eine kunstgeschichtliche Studie. Leipzig. 1855. G. Ungewitter: Lehrbuch der gotischen Konstruktionen. II. Auflage. Leipzig. 1875.

Dr. v. Essenwein, Exner, Hauenschild, Laubsch, Schmitt Handbuch der Architektur; Erster Teil: Allgemeine Hochbaukunde Darmstadt. 1883. Dritter Teil: Die Hochbaukonstruktionen. III.2. Raumbegrenzende Konstruktionen; III.2.(1) Erwin Marx: Wände und Wand-Oeffnungen. Darmstadt 1891. III.2.(2.)Fr. Ewerbeck u. Dr E. Schmitt. Einfriedungen, Brüstungen und Geländer, Balcons, Altane und Erker; Adolf Göller: Gesimse; Darmstadt 1891. Leipzig 1914. G. G. Ungewitter: Details für Stein-und Ziegel-Architektur im Romanisch-gotischen Stile. Berlin. 1906

There were relatively many books on mechanics in the library, which were then withdrawn from the library in the early 1900s, like the books of Kopka, Dr. Á. Ritter, G. Wanderley. It has made use of reinforced concrete: Kersten: Der Eisenbetonbau I. Teil. Ausführung und Berechnung der Grundformen II. Anwendungen im Hoch- und Tiefbau. Berlin 1909. 


\section{References}

Ackermann, K. (1994) "Industriebau", (Industrial building) Deutsche Verlags Anstalt, Stuttgart, pp. 14-15. ISBN 9783421028297.

Baustatik, 2018, [online] Available at: https://de.wikipedia.org/wiki/ Baustatik [Accessed: 10th May 2018]

Gesellschaft Bautechnikgeschichte, 2018, [online] Available at: https:// gesellschaft.bautechnikgeschichte.org/ziele/ [Accessed: 21st June 2018]

Giedion, S. (1928) "Bauen in Frankreich-Bauen in Eisen, Bauen in Eisenbeton", (Building in France, Building in Iron, Building in ferroconcrete) Klinkhardt und Biermann Verlag, Leipzig, p. 5 u.7.

Huning, A. (2007) "Kulturphilosophie der alltäglichen Lebenswelt", (Cultural philosophy of everyday life) Karin Fischer Verlag, Aachen, p. 164. ISBN 9783895147470.

Kaufmann, E. (1952) "Three Revolutionary Architects - Boullée, Ledoux, and Lequeu", American Philosophical Society, Philadelphia.

Krähling J., Baku E., Fehér K. (eds.) (2017) "Építeszeti Rajztár", (Architecture drawings archive) BME Építeszettörténeti Tanszék, Budapest.

Kurrer, K.-E. (2002) "Geschichte der Baustatik - Auf der Suche nach dem Gleichgewicht", (History of structural Engineering - In search of equilibrium) Verlag Ernst und Sohn. Berlin. ISBN 3-433-01641-0.

McKean, J. (1994) "Crystal Palace. Joseph Paxton and Charles Fox", Phaidon Press, London. ISBN 0-7148-2925-0

Mislin, M. (2002) "Industriearchitektur in Berlin 1840 - 1910", (Industrial Architecture in Berlin 1840 - 1910) Verlag Ernst Wasmuth, Tübingen-Berlin p. 234. ISBN 3803006171

Moravánszky, Á. (1988) "Építészet az Osztrák-Magyar Monarchiában", (Architecture in the Austrio - Hungarian Empire) (deutsche Ausgabe - German Edition), Corvina Kiadó, p. 67. ISBN 2638705904.

Nerdinger, W. (ed.) (1986) "Die Architekturzeichnung. Vom barocken Idealplan zur Axonometrie", (The Architectural drawing - from the baroque ideal plan to axonometry) Prestel Verlag, München. ISBN 13: 978791307213.

Nägelke, H. D. (2012) "Architekturzeichnungen sammeln", (Collecting architecture drawings) In: Natascha Meuser (Hg.). Handbuch und Planungshilfe - Architekturzeichnungen. DOM Publishers. Berlin. pp. 41-43. ISBN-10: 3869221321.

Neumeyer, F. (2002) "Quellentexte zur Architekturtheorie - Bauen beim Wort genommen", (Source texts for architectural theory - Construction taken at the word) München. Verlag C.H. Beck. 2002. pp. 198-202. ISBN 9783791326023.

Osterhammel, J. (2009) "Die Verwandlung der Welt - Eine Geschichte des 19. Jahrhunderts", (The transformation of the world - A story of the 19th century) C.H. Beck Verlag, München. pp. 909-949. ISBN 9783406614811 .

Pilsitz, M. (2012) "Műemlék az ipari építészetben" (Historic Preservation and industrial architecture) Építés-Építészettudomány. 40(1-2), pp. 97-112.

https://doi.org/10.1556/EpTud.40.2012.1-2.5

Pilsitz, M. (2016) "A korai ipari építészet mint a modern előfutára" (Historic industrial architecture as pioneer of modernity) Építés Építészettudomány, 44(3-4), pp. 227-245.

https://doi.org/10.1556/096.2016.44.3-4.3
Rheidt, K., Lorenz, W. (2018) "Groß Bauen. Großbaustellen als kulturhistorisches Phänomen. Kulturelle und technische Werte historischer Bauten", (Big building. Major construction sites as a cultural-historical phenomenon. Cultural and technical values of historcal buildings) Band 1. Birkenhäuser Verlag. Basel. ISBN 978-3-0356-1157-1.

Sartoris, A. (1932) "Gli elementi dell'architettura razionale", (The elements of rational architecture) Milano.

Schwarz, R. (1953) "Bilde Künstler, rede nicht", (Train artists, do not talk) Baukunst und Werkform. 6. Jahrgang. Frankfurt/Main. Heft 1. pp. 9-17.

Stark, J., Wicht, B. (1998) "Geschichte der Baustoffe", (Historical construcion materials) Springer Verlag, Berlin-Heidelberg. pp. 9-15. ISBN 3-7643-6345-2

Velde van de, H. (2003) " ..für den neuen Stil kämpfen ...", ("...Fight for the new style ...") Henry van de Veldes Beitrag zum Start in die Moderne vor 100 Jahren. Hrsg. Birgit Schulte im Auftrag der Henry van de Velde-Gesellschaft Hagen", Neuer Folkwang Verlag im Karl Ernst Osthaus-Museum. Hagen. ISBN 3-926242-53-1.

Wagenbreth, O. (1995) "Technikgeschichte und Industriearchitektur. Kritische Anmerkungen zur historischen Bearbeitung der Industriearchitektur", (Engineering history and industrial architecture. Critical comments on the historical treatment of industrial architecture) Technikgeschichte. 62(2), p. 138. ISSN: 0040117X. PPN129480053. PPN (digital): PPN513009361..

Wagner, O. (1896 / 1979) "Die Baukunst unserer Zeit", (The achitecture of our time) Wien, Erhard Löcker Verlag, Wien. ISBEN 9783902517777 . 